\title{
Analysis of the Effect of Earnings Persistence, Good Corporate Governance and Accrual Component to Earnings Quality on Banking in Indonesia in 2011 - 2015
}

\author{
Elok Faiqoh Himmah ${ }^{1,}$ Sedianingsih ${ }^{2}$ \\ Universitas Airlangga, Indonesia
}

\begin{abstract}
This study aims to examine empirically the effect of earnings persistence, good corporate governance, and the accrual component of the quality of earnings in the banking sector in Indonesia. Data analysis was performed using quantitative descriptive method that aims to provide an overview of the nature of things that took place at the time the research was done. The study sample consisted of 25 banks listed on the Indonesia Stock Exchange (IDX) with data for a period of 5 years (2011-2015). The results showed that the accrual component of earnings persistence and significant effect on the quality of earnings. The resulting value is significantly smaller than 0.05 . While GCG no significant effect on the quality of earnings in the banking sector in Indonesia, where significant value is greater than 0.05 .
\end{abstract}

Keyword: earnings persistence, GCG, accrual component, earnings quality

\section{Introduction}

The earnings information in the financial statements is generally important, especially for those who use financial statements for the purposes of contracting and investment decision making. From the perspective of contract objectives, profit information can be used to make decisions related to Good Corporate Governance practices, can also be used as a basis for salary allocation within an enterprise (12).

Management that has a particular interest will tend to compile earnings reports in accordance with its purpose and not in the interest of the principal. Under these circumstances, a control mechanism is required that aligns the differences of interests between the two parties. Good Corporate Governance Mechanism has the ability in relation to produce a financial statement that contains information of profit (2).

There are four mechanisms of Good Corporate Governance that are often used in various studies on Good Corporate Governance which aims to reduce agency conflicts, namely audit committee, independent commissioner, institutional ownership, managerial ownership. The structure of public share ownership by some researchers is believed to be able to influence the course of the company which ultimately affects the company's performance in achieving the company's goal of maximizing corporate value. This is because of the control they have.

The low quality of profits will be able to make decisions of the users as investors and creditors, so that the value of the company will be reduced. The value of the firm will be reflected in its stock market price. Profits as part of the financial statements that do not present the actual facts about the economic condition of a company can be doubted its quality. Profits that do not show actual information about management performance may mislead the users of the report. If such profits are used by investors to form the market value of the firm, then profit cannot explain the true market value of the company (2).

Profit management occurs when management uses certain decisions in financial statements and transactions to alter financial statements as a basis for the performance of a company that aims to mislead shareholders or to influence contractual results that rely on accounting figures reported. Earnings management can occur because managers are given the flexibility to choose the accounting method to be used in recording and disclosing their private financial information. In addition, this manipulation behavior also occurs because of high information asymmetry between management and others who do not have adequate resources, encouragement or access to information to monitor manager actions, so that management will attempt to manipulate the reported company performance for his own interests (5).

Managerial manipulation behavior that originated from this conflict of interest can be minimized through a monitoring mechanism that aims to align the various interests. First, by enlarging the ownership of the 
company's shares by management (managerial ownership), so the interests of the owner or shareholder will be aligned with the interests of the manager. Second, share ownership by institutional investors. They can monitor agents with large holdings. Through the role of monitoring by the board of directors (board of directors). The role of the board of directors with financial reporting is the size and independence of the board of directors affecting their ability to monitor the financial reporting process. This is in accordance with the spirit of Good Corporate Governance (GCG) which is proclaimed by the government against public companies.

This study refers to the research produced by Widayanti (2014) which suggests about the factors that affect the quality of profit. The results showed that growth opportunities positively affect the quality of profit, risk, firm size, CSR quality negatively affect earnings quality. While the persistence of profit, auditor quality, and capital structure have no effect on earnings quality. This research is able to produce a better research model compared to the reference research which is indicated by the increase of adjusted R2 value. (3)

Supervision is expected to improve the creation of Good Corporate Governance within the company. The benefits of Good Corporate Governance will be seen from the premium that investors are willing to pay for the company's equity (market price). If it turns out that investors are willing to pay more, then the market value of companies implementing Good Corporate Governance will also be higher than companies that do not implement or disclose their Good Corporate Governance (7).

The phenomenon of the influence of profit persistence, good corporate governance, and the accrual component based on the literature review and the results of previous research, the authors considered it necessary to present research on the influence of profit persistence, good corporate governance, and the accrual component to earnings quality, especially in banking companies in Indonesia, that is by proposing sample of research year 2011-2015.

\section{Literature and Hypothesis}

\subsection{Profit Quality}

The quality of profit can be defined as the profitability in explaining the information contained in it that can assist decision-making by decision makers (Dechow et al., 2010). Profit is an accrual accounting product and is used as a gauge of company performance management. The better the profit in describing the performance of the management the more qualified the profit. (5)

The quality of profit has many dimensions and can be measured with many sizes, one of which uses accruals. Accrual is the difference between net income and cash flow from operating activities (Richardson et al 2001). The main use of accruals is to reduce the time and incompatibility problems of cash flow (Dechow, 2001 in Schoemaker, 2013). Accrual makes operating cash flow into net income, thereby making the financial statements more informative of the company's performance. (9)

According to Suwardjono (2011: 463) investors through securities analysis, generally more basing themselves on the economic profit to predict cash flow or stock returns of the company in the future. Analysts see that accounting profits contain noise due to the application of PABU which in many cases does not reflect economic reality (eg the use of historical hiding) or due to earnings management. Therefore, if accounting profit is free from disruption and approaching economic profit, accounting earnings will be a reliable predictor as well. Thus, the proximity or correlation between accounting profit and economic profit will determine the quality of accounting earnings (earnings quality). (14)

\subsection{Profit Persistence}

Profit persistence is expected future earnings as reflected in current year earnings. Sustained profit for a future period is a reflection of quality profit (Ikhsan, 2012). Less-fluctuating profits are the hallmark of persistent earnings. Profit is one of the company's goals in addition to survival (going concern). Quality earnings are earnings that can reflect a continuation in the future. The preparation of financial statements aims to provide information useful for decision making. Achieving that goal, the Financial Accounting Standard sets out a criterion that accounting information must have to be used in decision making. The main criteria are relevant and reliable. Profit persistence is one component of predictive value of earnings, because persistence is an element of relevance, then persistence can be used to assess earnings quality.

Profit information is used to assess a company's performance, whether the company reports its earnings 
higher or lower than the previous year and assesses the prospects of the company in the future. The importance of profit information in making decisions causes the reported earnings quality of the company to be important for the users of financial statements to consider. Viewed from the Indonesian economy, so far accounting profits still attract the attention of investors, therefore potential investors are advised not only to see high profits, but persistent profit. Persistent earnings are profits that may reflect the continuation of future profits determined by its accruals and cash flows.

\subsection{Good Corporate Governace}

According to Sutedi (2011) Good Corporate Governance can be defined as a process and structure used by corporate organs (Directors, managers, shareholders, and others related to the development of companies in certain environments) to improve business success and corporate accountability to realize value shareholders in the long term while maintaining the attention of other stakeholders, based on legislation and ethical values. Banks are required to implement GCG principles in each of their business activities at all levels or levels of the organization including when composing vision, mission, strategic plan, policy implementation and steps Internal monitoring. The scope of application of GCG principles according to SE No. 15/15 / DPNP in 2013 Indonesian Bank shall at least be realized in 1) Implementation of duties and responsibilities of the Board of Commissioners; 2) Implementation of duties and responsibilities of the Board of Directors; 3) Completeness and performance of the Committee's duties; 4) Handling of conflict of interest; 5) Implementation of compliance function; 6) Implementation of internal audit function; 7) Implementation of external audit function; 8) Implementation of risk management including internal control system; 9) Provision of funds to related parties and large exposures; 10) Transparency of BUS financial and non financial condition, Good Corporate Governance implementation report and internal reporting; 11) Handling of conflict of interest. (13)

\subsection{Accrual Components}

Accrual is technically a profit difference with cash. Accrual is an accounting method in which receipts and expenses are recognized or recorded when transactions take place, not when cash for transactions is received or paid. Harahap (2010: 22) states accruals are: determination of income and expenses of the position of assets and liabilities set without seeing whether cash transactions have been done or not. The determination is not a cash engagement but based on its legal factor whether it is already a company's rights and / or obligations. If it should be recorded without waiting for payment or cash receipt. (6)

It can be concluded that the concept of accrual acknowledges a transaction, especially income and expenses, at the time of occurrence without being associated with cash transactions. This accrual basis of determination is also based on its legal factor whether or not it is a company's rights and obligations. The accrual basis will include the recording of transactions that occurred in the past and various rights and obligations in the future. In Study No. 14 issued by IFAC-Public Sector Committe, the financial statements presented on an accrual basis allow report users to:

- Assess the accountability of the management of all resources by an entity

- Assess the performance, financial position and cash flows of an entity;

- Decision-making on the provision of resources to, or conduct business with an entity. (1)

\subsection{Research Hypothesis}

The earnings persistence indicates a quality profit because it indicates that the company can retain earnings over time, and see that the company does not perform an action that could mislead the information user, since the firm's profit does not fluctuate sharply. The results of research Widayanti (2014) argued that the persistence of earnings significantly affect the quality of earnings. It is based on that the full profit persistence is oriented to the quality of profit, where the increase of earnings persistence, it is expected the quality of profit will be increased.(3)

\section{H1: Profitability has a significant effect on earnings quality in banking in Indonesia}

Implementation of GCG in the banking industry should always be based on 5 basic principles of transparency, accountability, responsibility, independency, fairness. Research Chusnulia Aryandhita Widayanti 
(2014) resulted that Good Corporate Governance have a significant and negative impact on earnings quality. This is because the implementation of GCG in the company is not oriented optimally to improve the quality of profit. (3)

\section{H2: Good Corporate Governance has significant effect to earnings quality in banking in Indonesia.}

According to Suwardjono (2005: 358) the disadvantages and advantages of accruals are accounting on the basis of accruals providing the entity's overall financial information both in asset ownership and the potential of ownership that is likely to be realized in the future as well as future liabilities. The principle or basis of accruals as the basic concept of accounting is more accepted and made into accounting policies of entities in general. The results of research Zaenal Fanani (2010), argued that the accruals affect the quality of earnings. This is a separate critique for accounting, where it is difficult to see the future predictions of the company only by relying on the financial statements based on the information of the past. (14)

\section{H3: Accruals have significant effect on earnings quality in banks in Indonesia.}

\section{Research Method}

\subsection{Research design}

This research is a quantitative descriptive research that aims to provide an overview of the nature of something that takes place at the time of research conducted. Researchers collect, arrange, and analyze data that can then be used to discuss the problem of research so that it can be drawn conclusions.

\section{Variable of Research and Definition of Operational Variable}

- Quality of profit, is the ability to explain the information contained in it that can assist decision-making by decision makers.

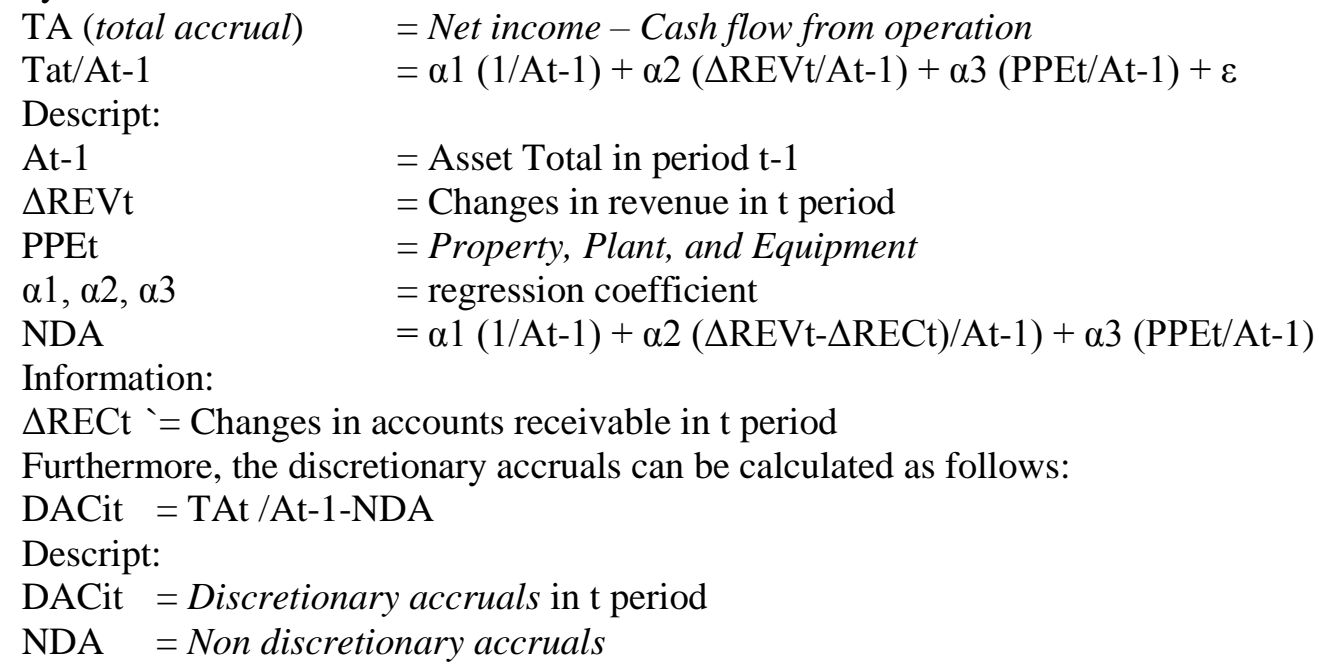

- Profit Persistence (X1), is expected future earnings as reflected in current year earnings. Sustained profit for a period to come is a reflection of a quality profit, measured by the following formula:

$$
\frac{\text { Earnings }_{\mathrm{jt}}}{\text { Shares outstanding }_{\mathrm{jt}}}=\beta_{0}+\beta_{1} \frac{\text { Earnings }_{\mathrm{it}-1}}{\text { Shares outstanding }_{\mathrm{jt}-1}}+\varepsilon_{\mathrm{Jt}}
$$

Descript:

Earnings $_{\mathrm{jt}} \quad=$ earnings before extraordinary items company $\mathrm{j}$ years $\mathrm{t}$

Earnings $_{\mathrm{jt}-1} \quad=$ earnings before extraordinary items company $\mathrm{j}$ last years

Shares outstanding $\mathrm{jt}_{\mathrm{jt}}=$ Shares outstanding company $\mathrm{j}$ years $\mathrm{t}$

Shares outstanding $\mathrm{j}_{\mathrm{j}-1}=$ Shares outstanding company $\mathrm{j}$ last years

- Good corporate governance (X2), as a process and structure used by corporate organs (Directors, managers, shareholders, and others related to the development of the company in certain environments) 
to improve business success and corporate accountability in order to realize value holders shares in the long term while still paying close attention to other stakeholders, based on legislation and ethical values.

- Accrual components (X3), is an accounting method in which receipts and expenditures are recognized or recorded when transactions occur, not when cash for transactions are received or paid, ie by using the formula:

$\sigma\left(\right.$ Earning $\left._{\mathrm{jt}}-\mathrm{CFO}_{\mathrm{jt}}\right)$

Descript:

Earning $_{\mathrm{jt}}=$ Company Operating Cash Flow j years $\mathrm{t}$

$\mathrm{CFO}_{\mathrm{jt}} \quad=$ Profit Before extraordinary items of company $\mathrm{j}$ years $\mathrm{t}$

\subsection{Data analysis technique}

Regression analysis is used to determine whether the hypothesis in this study proved to have an effect or no effect. the equations of multiple linear regression analysis below:

$$
\begin{aligned}
& \mathrm{Y}=\alpha+\mathrm{b}_{1} \mathrm{X}_{1}+\mathrm{b}_{2} \mathrm{X}_{2}+\mathrm{b}_{3} \mathrm{X}_{3}+e \\
& \text { Descript: } \\
& \mathrm{Y} \quad=\text { Quality of profit } \\
& \alpha \quad=\text { Constanta } \\
& \mathrm{b} \quad=\text { Regression coefficient of independent variables } \\
& \mathrm{X}_{1} \quad=\text { Profit Persistence } \\
& \mathrm{X}_{2} \quad=\text { Good corporate governance } \\
& \mathrm{X}_{3}=\text { Accrual components } \\
& e \quad=\text { Recidual }
\end{aligned}
$$

\section{Result}

Table I: HYPOTHESIS TESTING RESEARCH

\begin{tabular}{cccc}
\hline \hline Independent Variable & $\mathrm{t}$ & Sig. & Descript \\
\hline Profit Persistence & 7,956 & 0,000 & Significant effect \\
GCG & 0,596 & 0,552 & No significant effect \\
Accrual Components & 3,026 & 0,003 & Significant effect \\
\hline \hline
\end{tabular}

Based on the table, the level of influence given each independent variable to the dependent variable is as follows:

\subsection{The Effect of Profit Persistence on Profit Quality}

Profit Persistence factor (X1), has a tcount of 7,656 and a significant level of 0.000 . It shows that earnings persistence (X1) have a significant effect on earnings Quality (Y). The proof of the statement is based on the tcount value greater than the ttable value $(7,656>1,980)$ and the significant value smaller than the significant level $(0,000<0.05)$. Based on these results, the first hypothesis $(\mathrm{H} 1)$ which states that the persistence of earnings significantly affect the quality of earnings in banks in Indonesia is accepted.

According Richardson (2001), profit is not too fluctuating is a feature of persistent profit. Profit is one of the company's goals in addition to survival (going concern). Quality earnings are earnings that can reflect a continuation in the future. The preparation of financial statements aims to provide information useful for decision making. (9) The results of this study are in line with research produced by Chusnulia Aryandhita Widayanti (2014), which suggests that the persistence of earnings gives a significant effect on the quality of profit. (3)

Persistensi profit is a profit that can be used as an indicator of future earnings. Sustained earnings persistence is expressed as a profit that has high quality; otherwise if the unusual profit is expressed as a profit that has poor quality. The earnings persistence in the bank reflects the ability as a future earnings indicator produced by the company repetitive in the long term (sustainable). While unusual earnings or transitory earnings 
are temporarily generated earnings and can not be repeatedly generated (non-repeating), so it can not be used as an indicator of future period earnings.

\subsection{The Effect of Good Corporate Governance on Profit Quality}

GCG factor (X2), has a tcount of 0.596 and a significant level of 0,552. It shows that GCG (X2) has no significant effect to the quality of profit $(\mathrm{Y})$. The proof of the statement is based on the tcount value greater than the ttable value $(0,596<1,980)$ and the significant value greater than the significant level $(0,552>0,05)$. Based on these results, the second hypothesis (H2) which states that GCG has a significant effect on earnings quality in banking in Indonesia is rejected.

This does not support Cadburry's theory in Sutedi (2011), which suggests that Good Corporate Governance is the principle that directs and controls the company to achieve a balance between the power and authority possessed by the company in giving accountability to its shareholders in particular, and stakeholders in general. The discrepancies of the research results with the proposed theories are based on differences of interest in the perception of Good Corporate Governance where GCG is not entirely meant to gain management of banking management that leads to earnings quality. (13)

The results of research are in line with the research put forward Chusnulia Aryandhita Widayanti (2014), where Good Corporate Governance actually negatively affect the quality of profit. (3)

\subsection{The Effect of Acrual Component on Profit Quality}

Accrual Components Factor (X3), has a tcount of 3.026 and a significant level of 0.003 . It shows that Accrual Components (X3) have a significant effect on the Quality of profit (Y). The proof of the statement is based on tcount value greater than ttable (3.026> 1,980) and significant value smaller than significant level $(0,003<0,05)$. Based on these results, the third hypothesis $(\mathrm{H} 3)$ which states that the profit persistence significantly affect the quality of earnings in banks in Indonesia is accepted.

This result is in line with Harahap's stated theory (2010: 22) states that accruals are: the determination of income and expenses from the position of assets and liabilities is determined regardless of whether the cash transaction has been done or not. The determination is not a cash engagement but based on its legal factor whether it is already a company's rights and / or obligations. If it should be recorded without waiting for payment or cash receipt. (6)

The results of research are not in line with the results of research Chusnulia Aryandhita Widayanti (2014), which suggests that the accruals have a significant effect on the quality of profit. (3)

The amount of accrual is the amount of income recognized in the union rights of the business arising from the delivery of goods to external parties. The amount of income is recognized when the business unity rights arise because of the delivery of goods to an outsider and the cost is recognized when the liability arises because of the use of the economic resources attached to the delivered goods. Companies with large accruals will have a lower earnings persistence resulting in a decrease in earnings performance in the next year.

\section{References}

[1] Bissessur, Sanjay Wikash. 2008. Earnings Quality and Earnings Management: The Role of Accounting Accruals. Dissertation. Amsterdam: Aculty of Economic and Business, University of Amsterdam.

[2] Boediono, Gideon.2010. Kualitas Laba: Studi Pengaruh Mekanisme Corporate Governance dan Dampak Manajemen Laba dengan Menggunakan Analisis Jalur. Simposium Nasional Akuntansi (SNA) VIII Solo.

[3] Chusnulia Aryandhita Widayanti. 2014. Faktor-faktor yang Mempengaruhi Kualitas Laba pada Perusahaan High Profile yang Terdaftar di BEI. STIE Bank BPD Jateng. Jurnal Dinamika Ekonomi \& Bisnis. Jepara: Universitas NU.

[4] Damodar, Gujarati. 2011. Dasar-Dasar Ekonometrika. Jakarta: Erlangga.

[5] Dechow, P. and I. Dichev. 2002. The Quality of Accruals and Earnings: The Role of Accrual Estimation Errors. The Accounting Review, 77 (Supplement), 35-59.

[6] Harahap, Sofian Safri. 2012. Analisis Kritis Atas Laporan Keuangan. Jakarta: Rajawali Persada.

[7] Kusumawati, D.N \& Riyanto. 2005. Corporate Governance dan Kinerja: Analisis Pengaruh Compliance Reporting dan Struktur Dewan terhadap kinerja. SNA VIII. 
[8] Rahma Wijayanti. 2016. Pengaruh Volatilitas Laba, Perataan Laba, dan Corporate Governance terhadap Kualitas Laba Bank Syariah dan Konvensional. Simposium Nasional Akuntansi XIX, Lampung, 2016. Jakarta: Universitas Indonesia.

[9] Richardson, S., R. Sloan, M. Soliman, I. Tuna. 2001. Information in Accruals About the Quality of Earnings. Working Paper, University of Michigan business school.

[10] Rinawati, A. 2011. Kualitas Laba. http://annyriwayati.blogspot.com/. Diakses 15 Oktober 2016.

[11] Santoso, Singgih. 2012. Buku Latihan SPSS Statistik Parametrik. Jakarta: Elex Media Computindo.

[12] Sugiarto dan Dergibson Siagian, 2009. Teknik sampling, Jakarta: Gramedi Pustaka Utama, 2001

[13] Sutedi, Adrian. 2011. Good Corporate Governance. Jakarta : Sinar Grafika.

[14] Suwardjono. 2005. Teori Akuntansi. Yogyakarta: Penerbit BPFE.

[15] Zaenal Fanani. 2010. Analisis Faktor-Faktor Penentu Persistensi Laba. Jurnal Akuntansi dan Keuangan Indonesia.Volume 7 - No. 1, Juni 2010. Jakarta: Universitas Airlangga. 